\title{
PERANAN PROTEKTIF DAN NON-PROTECTIF NITRIC OXIDEs (NOs) PADA RESPON IMUN
}

\author{
Basuki Budiman \\ Pusat Penelitian dan Pengembangan Gizi dan Makanan, Depkes RI
}

\begin{abstract}
THE ROLE OF PROTECTIVE AND NON-PROTECTIVE NITRIC OXIDES (NOs) IN IMMUNE RESPONS
\end{abstract}

Nitric oxides (NO), included in this term are radical $\mathrm{NO}$, (ionic) $\mathrm{NO} ; \mathrm{NO}, \mathrm{NO}_{2}, \mathrm{NO}_{2}^{-}, \mathrm{NO}_{3}^{-}, \mathrm{N2O}$, $\mathrm{N} 2 \mathrm{O} 4$, S-nitrosothiols, peroxynitrite (ONOO-), and nitrisyl-metal complex. NOs are radical substances which have characteristic both protective and non-protective immunity due to unable to distinguish pathogen DNA or host DNA. NO is by_product of arginine metabolism. NO plays roles in muscle relaxation to prevent platelets aggregation, as intra cell neurotransmitter, mediated macrophage of tumor cell and bacteria. The activity is under controlled by NO-synthetase (NOS) which has three isomers, namely NOS1 or neural NOS (nNOS), NOS2 or inducible NOS (iNOS) and NOS3 or endothelial NOS (eNOS). The role of iNOS/NO in immune system could be as a protective and non-protective which work simultaneously and depend on the immune system equilibrium. The function of $\mathrm{iNOS} / \mathrm{NO}$ is as regulator and effector. As regulator the function includes change of lymphocyte from proliferation and modulated cytokine response. As effector the function includes necrosis and immnunoprotective activities. The main target of $\mathrm{NO}_{2}$ toxicity is lungs but depends on the concentration of toxicity and duration of exposure to the target

Keywords: arginine, immonology, NOS, nitric oxide, protective

\section{PENDAHULUAN}

$\mathrm{N}$ itrogen Oksida merupakan istilah yang digunakan untuk kelompok ikatan kimia unsur $\mathrm{N}$ dan $\mathrm{O}$, termasuk dalam kelompok ini, radikal $\mathrm{NO}$, $\mathrm{NO}-\mathrm{NO}, \mathrm{NO}_{2}, \mathrm{NO}^{2-}, \mathrm{NO}^{3-}, \mathrm{N}_{2} \mathrm{O}_{3}, \mathrm{~N}_{2} \mathrm{O}_{4}$, Snitrosothiols, peroxynitrite (ONOO-), kompleks nitrisyl-metal. Di alam bebas NO dioksidasi menjadi NO2 yang merupakan prekursor ozone (03). Keberadaan NO, NO2 dan N2O3 terjadi hampir berbarengan. Oleh karena itu, istilah oksida-oksida nitrogen dan NO yang digunakan dalam pustaka, menunjuk pada molekul-molekul tersebut. NOX adalah istilah yang digunakan terutama dalam polusi udara ${ }^{1,2}$.

Membahas NO tidak dapat dilepaskan dari pembahasan NOS (Nitric Oxide synthase). Ada tiga isoform NOS yaitu NOS1 atau nNOS, NOS2 atau iNOS dan NOS3 atau eNOS ${ }^{1,3}$. nNOS adalah tipe neural untuk NOS yang diekspresikan pada sel syaraf, iNOS untuk NOS yang diaktifkan (inducible) oleh sitokin, dan eNOS untuk NOS yang ditemui pada lapisan endotelial pembuluh darah. Istilah cNOS digunakan untuk nNOS dan eNOS secara bersama-sama. Di antara ketiga NOS itu, iNOS hanya diekspresikan pada keadaan tertentu sebagaimana pengaturan sistem imun oleh sitokin atau induksi patologik karena adanya endotoksin dan sitokin ${ }^{1,3}$.

\section{Produksi NO}

Secara fisik NO2 adalah gas yang berwarna kecoklatan hasil ikutan utama dari pembakaran pada temperatur tinggi. NO di alam bebas merupakan hasil ikutan fermentasi an-aerobik tanaman pangan (crops). Di dalam tubuh, NO merupakan hasil lain reaksi koversi L-arginin menjadi sitrulin dalam sel. 


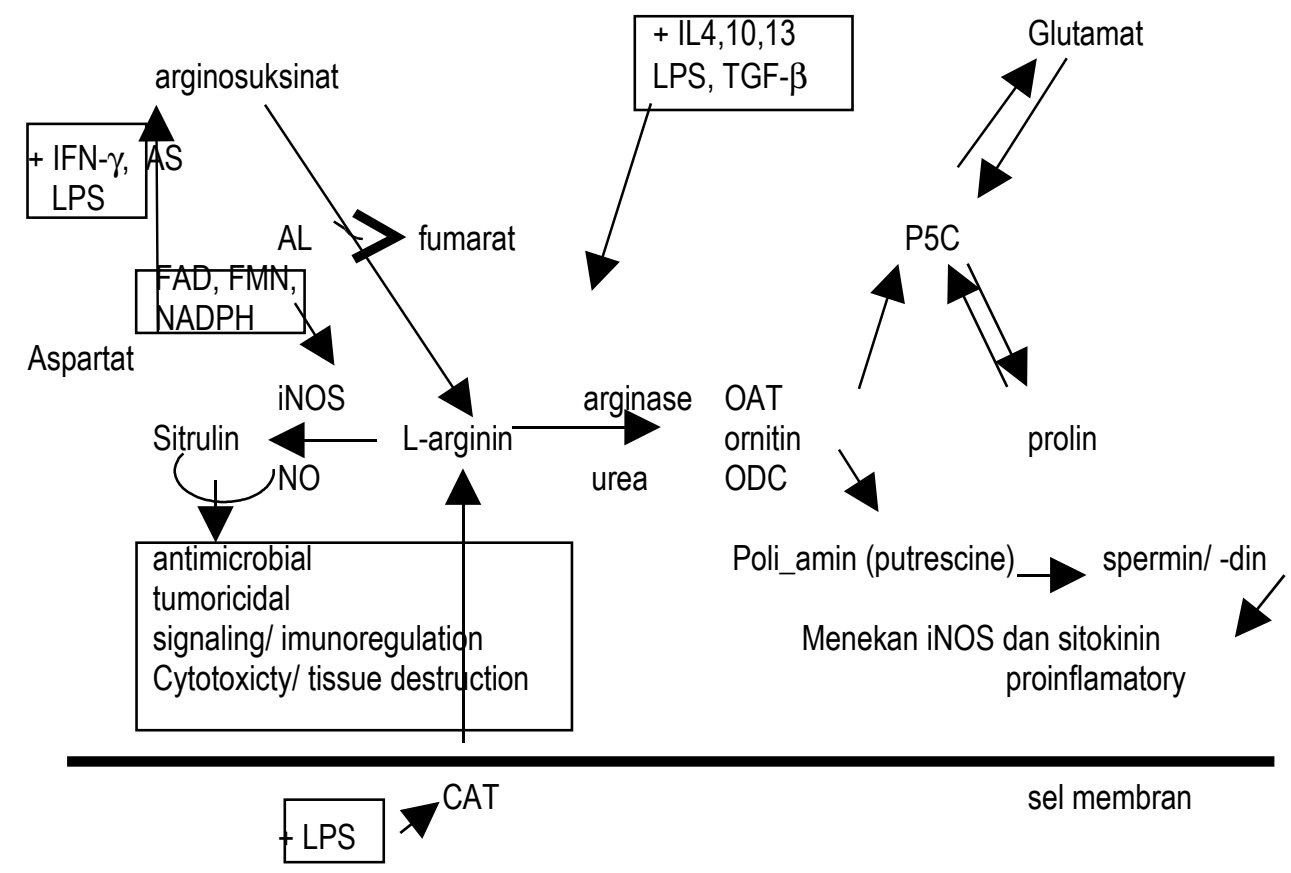

darah L-arginin

$$
\begin{array}{|lr|r}
\hline+ \text { IFN-g, TNF, IL1,2, MIF } \rightarrow & \text { iNOS } \\
\text { +/- LPS, IL10, IFNab, } & \rightarrow & \text { iNOS } \\
- \text { - TGF-b, IL4,11,13 } & \rightarrow & \text { iNOS }
\end{array}
$$

diadaptasi dari MORI ${ }^{4}, 2004$ dan Bogdan' 2001

Arginin merupakan bahan dasar proses sintesa urea, poli_amin (putresin), kreatinin fosfat dan NO. Arginin diangkut dari darah ke sel oleh isoform CAT (cationic amino acid transporter). Kemudian terjadi siklus arginin, sitrulin, arginosuksinat, arginin. NO dihasilkan dari konversi arginin yang diperantarai oleh iNOS. Sintesa arginosuksinat berasal dari sitrulin dan aspartat dengan diperantarai arginosuksinatsintetase (AS), kemudian menjadi arginin dengan membentuk fumarat diperantarai arginosuksinat lyase (AL). Urea terbentuk dari sintesa ornitin dengan hadirnya enzim arginase, yang selanjutnya membentuk glutamat dan prolin melalui pirolin-5karbosilat dengan perantara ornitin aminotransferase (OAT). Sintesa poli_amin dari ornitin diperantarai oleh ornitin dekarboksilase. Proses ini dapat disimak pada bagan 1.

AS dan AL diekspresikan terutama di ginjal dan hati. AS dan AL terinduksi pada saat iNOS diinduksi oleh sel-sel yang terinfeksi oleh bakteri lipo-poli-sakarida (LPS) dan sitokin (IFN $\gamma$, interferon gamma). Ko-induksi iNOS dan AS secara in vivo ditemui di paru-paru, jantung, hati, empedu, otot, testis tikus setelah diberi LPS. Hal ini cukup menjadi bukti bahwa iNOS bekerja secara in vivo di sel manapun.

Neural dan epitel NOS (cNOS) secara bersama diekpresikan dan diatur oleh konsentrasi kalsium melalui interaksi dengan 
kalmodulin. Komplek kalsium-kalmodulin (Ca/CaM) menstabilkan homodimer yang setiap monomer-nya mengandung enzim reduktase dan oksigenase. Dalam enzimenzim ini terdapat kofaktor Flavin Adenin Dinukleotida (FAD), Nikotinamid Adenin Dinukleotida Phosphat-Hidrogen (NADPH), Flavin Mono Nukleotida (FMN) atau heme dan tetra-hidro-biopterin (B4H). B4H penting bagi formasi NOS dimer yang merupakan bentuk sintetase aktif. Ketergantungan kepada kalmodulin ini menjadi model untuk menjelaskan peranan glutamat dalam neurotoxicity dalam CNS. Neurotoxicity adalah mekanisme glutamat yang menginduksi kematian sel syaraf. Glutamat dalam sel syaraf mengaktifkan reseptornya yaitu NMDA (derivatif aspartat yang dimetilasi). Reseptor ini selektif terhadap ion kalsium, sehingga menstimuli pengikatan eNOS pada sintetase melalui komplek $\mathrm{Ca} / \mathrm{CaM}$. Terbentuknya NO mengakibatkan kematian sel dengan cara perusakan sel, menekan respirasi mitokondria yang akhirnya menguras energi dalam sel. Sel syaraf (neuron) sangat sensitif terhadap kerusakan kapasitas mitokondria dalam mensintesa adenosin triphosphat (ATP), karena neuron sangat tergantung pada degradasi oksidatif glukosa dan keton bodies. ATP digunakan untuk mekanisme neuro-transmitter ${ }^{5,6}$.

Oleh karena itu NO hanya dapat diproduksi jika tersedia arginin. Uptake arginin dapat dihambat oleh L-lysin yang mekanisme kerjanya berlawanan dengan reseptor glutamat, NMDA. Produksi NO dalam sel neuron dan endotelial oleh cNOS hanya sedikit, dan untuk jangka waktu yang pendek. Gen NOS makrofag lebih pendek daripada gen NOS neural, namun menyumbang 50 persen identitas dalam sekuen asam amino ${ }^{6}$.

\section{Metabolisme}

NO dapat merusak jaringan karena sifat radikalnya dan dapat pula sebagai sitoprotektif yang melindungi kehidupan sel dengan cara membunuh mrikroorganisme patogen. Misalnya, peroksinitrit merusak DNA bakteri Heliobacter pylori yang menyebabkan tukak dan kanker lambung. Namun demikian produksi peroksinitrit yang berlebihan dapat menyebabkan septic shock karena sifat radikal NO yang tidak dapat membedakan DNA patogen dengan DNA host ${ }^{1,3,4}$.

$$
\text { Inducible NOS (iNOS) yang }
$$
diekspresikan sebagai mekanisme darurat untuk menekan pertumbuhan tumor dalam epitel gaster, jaringan payudara dan otak. Endotoksin bakteri merangsang gene iNOS yang pada gillirannya akan memproduksi NO pada kadar yang tinggi untuk merusak DNA patogen dan menghambat metabolisme produksi energi yang dibutuhkan patogen untuk melakukan pembelahan sel. Namun demikian, produksi yang berlebih ternyata dapat merugikan host karena radikal bebas NO juga merusak sel dan jaringan host. Di samping septic shock, penyakit lain yang dikaitkan dengan overproduksi NO adalah cerebral infarction, diabetes mellitus dan gangguan neurodegeneratif. Keberadaan LArginin merupakan limiting faktor dalam produksi $\mathrm{NO}^{4}$.

\section{Fungsi-fungsi NO}

Fungsi NO antara lain dalam relaksasi otot polos, mencegah agregasi platelet, neurotransmitter dalam sel syaraf, mediasi makrofag dalam menghancurkan sel tumor dan bakteri ${ }^{1,4}$. NO merupakan respon stres yang dapat melindungi jaringan inang (host) dari mikroba patogen dengan cara merusak DNA /membunuh mikroba patogen tersebut atau NO dapat juga menyebabkan kerusakan (injury) karena sifat kimiawi radikalnya. NO bersama-sama TNF $\alpha$ bersifat pro-inflamatory dan potensial menjadi mediator kerusakan jaringan. Hal ini telah dibuktikan oleh Jabs, dkk (2004) ${ }^{7}$ pada tikus MRL/ MpJ.

\section{Fungsi Protektif \\ NO sebagai protektor \\ iNOS/NO dalam sistem imun berfungsi sebagai regulator dan efektor. Sebagai regulator termasuk efek imunosupresif, misalnya menghalangi proliferasi limfosit dan modulasi respon sitokin. Sebagai efektor termasuk efek imunopatologi (misalnya}


penghancuran jaringan) dan aktifitas imunoprotektif (misalnya, membunuh mikroba patogen atau apoptosis $T$ sel autoreaktif). Namun perlu dicatat bahwa iNOS/NO dalam sel, kedua fungsi bekerja secara simultan, keduanya tidak dapat dipisahkan secara mutually exclusive. Oleh karena itu, pemisahan sebagai protektif dan non protektif kurang tepat karena sangat tergantung pada keadaan dan keseimbangan sistem imun.

\section{NO dan Cacing}

Partisipasi NO dalam pertahanan tubuh melawan mikroba, telah banyak diuraikan dalam jurnal laporan penelitian, termasuk di antaranya dengan cacing. Misalnya Schistosoma mansoni dapat dibunuh oleh makrofag dengan melibatkan NO. Pada percobaan dengan tikus yang terkena infestasi S. Mansoni, NO membatasi terjadinya kerusakan hati, yang tampak dari terbentuknya granuloma yang membungkus telur cacing ${ }^{8}$.

Studi Long, dkk ${ }^{8}$ pada siput yang diinfeksi $S$ japonicum dan dibandingkan dengan $S$ mansoni memberikan hasil yang agak berlawanan. Ternyata cacing ini memberikan perlawanan dengan cara mengekspresikan iNOS-nya baik sel cacing dewasa, pada larva bahkan pada telornya. Pengaruh NO atau iNOS pada kerusakan hati tikus ternyata tergantung pula dengan inhitor iNOS yang digunakan. Tikus yang diberi inhibitor iNOS (amino guanidin) memperlihatkan liver patologi memburuk. Di lain pihak pemberian dengan L-NAME menyebabkan berkurangnya kerusakan hati secara nyata.

Aktivasi inflammantory peritoneal macrophag oleh IFN- $\gamma$ dan kofaktor sitokin lainnya atau LPS merangsang (induce) NO sebagai molekul efektor membasmi cacing. Pembasmian larva, secara in vitro, dihambat dengan analog arginin, NMMA atau dengan banyak Fe ke dalam media kultur ${ }^{8,12}$.

\section{NO dan mikroba/virus}

Sebagai anti mikroba iNOS/NO tidak bersifat universal. Beberapa bakteri Mycobacterium avium, Mycobacterium tubercolosis, Salmonella tahan terhadap NO. NO juga berperan melawan virus seperti Vaccinia, Sivian virus 40 (SV40), Herpes simplex virus-1 (HSV-1), Human Immunodeficiency Virus (HIV), Lymphocyte chorio meningitis virus (LCMV), Lactate Dehydrogenase elevating Virus (LDV), Borne Disease Virus (BDV). Aktivitas NO melawan virus terjadi pada tahap replikasi virus. Dengan demikian penyebaran virus dihambat ${ }^{9}$. Menurut Nikfarjam, dkk ${ }^{10}$ (1999) yang melakukan penelitian produksi NO dengan rubella, mengungkapkan bahwa NO diproduksi banyak ketika cell mediated immunity (CMI) belum aktif. NO terutama derivatif oksigennya, peroksinitrit, merusak DNA mikroba/ virus dengan modifikasi kimia sehingga terjadi mutasi atau NO menghalangi kerja enzim ribonuklotida reduktase. Kerusakan DNA dan hambatan kerja enzim menyebabkan sel mikroba (virus) terkuras energinya untuk sintesa nukleotida dan perbaikan sel..$^{9,10}$.

Namun tidak semua virus dapat dihancurkan oleh NO. Beberapa virus yang tahan terhadap NO seperti virus influensa , sinbis dan encephalitis kecuali golongan Flaviviridae seperti Japan Encephalitis Virus ${ }^{9}$.

\section{NO dan kanker}

iNOS yang diekspresikan sebagai mekanisme darurat untuk menekan pertumbuhan tumor di epitel gaster, jaringan payudara, dan otak berkaitan dengan septic shock. NO merusak DNA patogen dan menghambat produksi energi metabolik yang dibutuhkan untuk pembelahan sel. Bakteri endotoksin menginduksi gen iNOS untuk memproduksi NO dalam jumlah banyak. Namun radikal bebas tidak dapat membedakan DNA patogen dan DNA inang (host). Overproduksi NO dapat menyebabkan septic shock ${ }^{11}$.

\section{Fungsi non-protektif NO dan polusi}

Polusi udara dari NO2 adalah hasil dari emisi kendaraan yang bersifat racun dan dapat berakibat kematian jika dihirup dalam konsentrasi tinggi. Toksisitas NO2 
tergantung dari konsentrasi dan lama terpapar. Pada konsentrasi 50 ppm dapat menyebabkan batuk, hemoptysis, dyspnea, nyeri dada. Paparan lebih dari 100 ppm dapat menyebabkan edema pada paru-paru yang bisa menjadi kematian atau paling tidak sakit paru-paru kronis ${ }^{2}$.

Lokus utama toksisitas NO2 adalah paru-paru. NO2 yang masuk ke dalam paruparu dapat dikonversikan menjadi NO, HNO3, dan HNO2 pada saluran distal yang secara langsung menimbulkan pneumositis tipe I dan ciliated airways cell. NO2 memunculkan generasi radikal bebas pada terminal bronchiole, yang pada gilirannya akan menyebabkan oksidasi protein, pembentukan lipid peroxidasi dan selanjutnya merusak sel membran. NO2 juga merusak fungsi imun dan kerja makrofag yang akhirnya meruntuhkan pertahanan tubuh terhadap infeksi ${ }^{1,2,3}$

Nitrogen monooksida (NO) yang diserap melalui paru-paru masuk ke dalam aliran darah terikat hemoglobin $(\mathrm{Hb})$ berbentuk nitrosil hemoglogin. Dalam kadar yang tinggi menyebabkan methemoglobinemia. Keadaan ini pada gilirannya akan menyebabkan kerusakan proses oxygenasi pada jaringan. Afinitas $\mathrm{NO}$ dengan $\mathrm{Hb}$ sangat tinggi, ribuan kali lebih besar daripada afinitas CO2. Sebagai transmiter kimiawi, NO berumur pendek yang dengan mudah menembus membran karena NO mempunyai semacam dua kutub elektronegatif yang berada di unsur oksigen dan nitrogen. Sifat elektronegatif ini membuat NO menjadi hidrofobik. Walaupun tergolong radikal bebas, namun NO tidak seradikal kelompok radikal bebas oksigen. NO sangat labil dan dengan mudah bereaksi dengan oksigen lain membentuk N2O3 atau dengan superoksida (O2') membentuk peroxinitrit (ONOO-).

Pembentukan peroksinitrit ini juga terjadi dalam sel. Kerugian karena NO telah banyak disinggung dalam paragraf-paragraf sebelumnya.Kerugian terutama karena over produksi NO, yang menyebabkan terkurasnya energi dalam sel yang akhirnya menyebabkan kematian sel ${ }^{4}$.
Sagoo $^{11}$ (2004) mengungkapkan hasil penelitiannya bahwa induksi apoptosis terjadi karena sinergi kerja sitokin IL1, IFN- $\gamma$ dan TNF. Cytokine mediated cytotoxicity berkorelasi erat dengan aktivasi (oleh NF匹B, p38, dan STAT-1) sel endotel, upregulated iNOS dan peningkatan produksi NO. Namun dengan pemberian perlakuan secara farmakologi, efek iNOS sebagai proinflamantori dapat dihalangi.

\section{KESIMPULAN}

1. Nitric Oxide merupakan hasil lain dari siklus konversi L-arginin menjadi L_sitrulin dengan mediasi NOS dan banyak kofaktor.

2. Nitric Oxide berfungsi sebagai protektif sekaligus non-protektif. Kedua fungsi ini tidak dapat dipisahkan secara eksklusif.

\section{RUJUKAN}

1. Bogdan, Christian. Nitric oxide and the immune response. Review. Nature immunology. 2001. 2(10) http://immunol.nature.com

2. Peterson, JS., Suzanne M Miller and B Cairns. Nitrous Dioxide. eMedicineToxicity, 2005. http://www.emedicine.com/

3. Bogdan, Christian The Multiplex Function of Nitric Oxide in (Auto)immunity. J. Exp. Med. 1998. 187(9):1361-65. http://www.jem.org

4. Mori, Masataka and Tomomi Gotoh. Arginine Metabolic Enzyme, Nitric Oxide and Infection. J. Nutr. 2004. 134:2820S25S. http://www.nutrition.org

5. Anonimus, What is Life., Nitric Oxide. Overview. Cited on May 2006.

http://www.whatislife.com/reader2/Meta bolism/

6. James SL. Role of nitric oxide in parasitic infections. Microbiol. Rev. 1995;59(4):533-547 [PubMed] 
7. Jabs DA, HC Gerard, Y Wei, AL Cambell, AP Hudson, EK Akpek, etal. Inflammatory Mediators in Autoimmune Lacrimal Gland Disease in MRL/Mpj Mice. Investigative Opthalmology and Visual Science. 2004;45:2293-8.

8. Long, XC-., M Bahgat, K Chlichlia, A Ruppel and Y-L Li. Detection of inducible nitric oxide synthase in Scistosoma japonicum and $S$ mansoni. J Helminth. 2004;78:47-50

9. Reiss CS and T Komatsu. Does Nitric oxide play acritical role in viral infections? Minireview. J Virol. 1998;72(6):4547-51

10. Nikfarjam, L., AZ Hosseini and A Pourfathollah. Nitric Oxide Production and Cell Mediated Immunity Evaluation Following BALB/c Mice Vaccination with Rubella Vaccine. Irn J Med Sci 1999;24 (3\&4):135-7

11. Sagoo, P., G Chan, DFP Larkin and AJT George. Inflammatory Cytokines
Induce Apoptosis Corneal Endothelium through Nitric Oxide. Investigative Opthalmology and Visual Science. 2004;45:3964-73

12. Terraso, D. E. Coli's defense mechanism uncovered-Iron key to nitric oxide reduction. (Comment). Medical News $\quad 2005$. http://www.medicalnewstoday.com/. Cited on May 2006.

13. NN. 1999. A Compilation of Vital Research Updates on Human Nutrition. Albion Research Notes. Vol.8 No. 1.

14. Abbas, AK dan AH Lichtman. Cellular and Molecular Immunology. Saunders, Vth Edition. 2003

15. Yee, LJ., S Knapp, D Burgner, BJW Hennig, AJ Frodsam, M Wright, et al. Inducible nitric oxide synthase gene (NOS2A) haplotypes and the outcome of hepatitis $C$ virus infection. Genes and Immunity. 2004:1-5. www.nature.com/gene. Cited on May 2006. 
Tabel Lampiran 1

Ikhtisar Fungsi NO dalam sistem imun

\begin{tabular}{|c|c|c|c|}
\hline Kategori & Poduser NO & Efek fenotip NO & $\begin{array}{c}\text { Contoh mekanisme } \\
\text { molekuler }\end{array}$ \\
\hline
\end{tabular}




\begin{tabular}{|c|c|c|c|}
\hline Anti mikroba & $\begin{array}{l}\text { Makofag, } \\
\text { mikroglia, } \\
\text { neutrofil, eosin, } \\
\text { fibrob endotel/ } \\
\text { epitel sel, } \\
\text { astroglia }\end{array}$ & $\begin{array}{l}\text { Fungsi efektor } \\
\text { Membunuh/ } \\
\text { mengurangi replikasi } \\
\text { agen infeksi }\end{array}$ & $\begin{array}{l}\text { Efek langsung NO pd } \\
\text { patogen } \\
\text { Efek tak langsung jalur NOS } \\
\text { (mis. Reaksi NO dg mol. } \\
\text { Efektor, deplesi arginin) }\end{array}$ \\
\hline Anti tumor & Makrofag, eosin & $\begin{array}{l}\text { Membunuh/ } \\
\text { menghambat tumbuh } \\
\text { sel tumor }\end{array}$ & $\begin{array}{l}\text {-menghambat kerja enzim } \\
\text { pertumbuhan tumor, } \\
\text {-menghambat pertumbuhan } \\
\text { via iNOS-dependent } \\
\text { depletion of Arginin } \\
\text {-cell-cycle arrest } \\
\text {-induksi apoptosis (dg } \\
\text { aktifasi caspase dan } \\
\text { akumulasi p53) } \\
\text {-Sensitisasi sel tumor untuk } \\
\text { TNF-induced cytotoxicity }\end{array}$ \\
\hline Imunopatologi & $\begin{array}{l}\text { Makrofag, } \\
\text { mikriglia, } \\
\text { astroglia, } \\
\text { keratinosit, } \\
\text { mesanglia }\end{array}$ & $\begin{array}{l}\text { Nekrosis/ fibrosis } \\
\text { parenkhim }\end{array}$ & $\begin{array}{l}\text {-Apoptosis sel parenkhim } \\
\text {-degradasi matriks ekstra- } \\
\text { sel } \\
\text {-deposisi matriks, proliferasi } \\
\text { sel mesenkhim } \\
\text {-influk sel-radang via } \\
\text { regulasi kemokin }\end{array}$ \\
\hline $\begin{array}{l}\text { anti-inflamantori } \\
\text { Imunosupresif }\end{array}$ & $\begin{array}{l}\text { Makrofag (fenotip } \\
\text { supressor) }\end{array}$ & $\begin{array}{l}\text { Fungsi } \\
\text { imunoregulator } \\
\text { Menghambat: } \\
\text {-proliferasi sel T, sel } \\
\text { B } \\
\text {-produksi antibodi } \\
\text { CD5+ sel B } \\
\text {-Autoreaktif } \\
\text { diversifikasi sel B } \\
\text { dan T } \\
\text {-rekrutmen leukosit } \\
\text { (adesi, ektravasasi, } \\
\text { kemotaksis) }\end{array}$ & $\begin{array}{l}\text {-Apoptosis sel T IAPC } \\
\text {-Downregulasi MHC klas II, } \\
\text { mol. Costimulatory/sitokin } \\
\text {-disrupsi signaling cascade } \\
\text { dan faktor traskripsi } \\
\text {-menghambat sintesa DNA } \\
\text {-downregulasi adesi } \\
\text { molekul/ kemokin }\end{array}$ \\
\hline $\begin{array}{l}\text { Modulasi } \\
\text { produksi, fungsi } \\
\text { sitokin, kemokin, } \\
\text { faktor tumbuh } \\
\text { (efek pro/anti } \\
\text { inflamantori) }\end{array}$ & $\begin{array}{l}\text { Makrofag, sel T, } \\
\text { endotel, fibroblas }\end{array}$ & $\begin{array}{l}\text { regulasi (up/down) } \\
\text {-IL1,8,10,12,18, } \\
\text { IFN } \gamma, \text { TNF, TGF } \beta \text {, G- } \\
\text { CSF, M-CSF, VEGF, } \\
\text { MIP-1 } \alpha, \text { MIP-2, } \\
\text { MCP-1 }\end{array}$ & $\begin{array}{l}\text { Modulasi: } \\
\text { Signaling cascade } \\
\text {-Regulasi stabilitas dan } \\
\text { translasi mRNA } \\
\text {-Faktor transkripsi } \\
\text {-Latent cytokine precursor } \\
\text { complexes } \\
\text {-enzim-enzim yang } \\
\text { memproses prekursor } \\
\text { sitokin }\end{array}$ \\
\hline
\end{tabular}


Disadur dari: Bogdan, 2001

Tabel Lampiran 2

Ekspresi dan fungsi NOS dalam fagosit, sel dendrit, NK, T dan B

\begin{tabular}{|l|l|l|l|}
\hline Tipe sel & Stimulus & NOS isofom & Kemungkinan fungsi NO \\
\hline
\end{tabular}




\begin{tabular}{|c|c|c|c|}
\hline Tikus/manusia & $\begin{array}{l}\text { IFNg+LPS; IFN } \\
\alpha / \beta \\
\text { IL4 plus anti- } \\
\text { CD23 }\end{array}$ & $\begin{array}{l}\text { Makrofag } \\
\text { iNOS (R,P,A) }\end{array}$ & $\begin{array}{l}\text { Anti mikroba } \\
\text { Supresi sel T } \\
\text { Anti radang? }\end{array}$ \\
\hline $\begin{array}{l}\text { Alveolar } \\
\text { marmut/rat }\end{array}$ & $\begin{array}{l}\text { None or lung } \\
\text { surfactan }\end{array}$ & eNOS $(R, P, A)$ & Belum diketahui \\
\hline $\begin{array}{l}\text { Sel pro_monosit } \\
\text { man } \\
\text { (U937) }\end{array}$ & $\begin{array}{l}\text { sCD23 atau anti- } \\
\text { CD11b/c }\end{array}$ & eNOS $(R, P, A)$ & Not applied \\
\hline LC primer tikus & $\begin{array}{l}\text { I } \\
\text { FN } \gamma+\text { LPS; } \\
\text { IFN } \gamma+L \text { major } \\
\text { LPS; IFN } \gamma+L P S\end{array}$ & $\begin{array}{l}\quad \text { sel Dendrit } \\
\text { no iNOS mRNA } \\
\text { detectable } \\
\text { iNOS }(R, P, A)\end{array}$ & $\begin{array}{l}\text { pro-radang } \\
\text { menekan pertumbuhan } \\
\text { mikroba }\end{array}$ \\
\hline $\begin{array}{l}\text { BM-DC tikus } \\
\text { (imatur) }\end{array}$ & $\mathrm{IFN} \gamma+\mathrm{LPS}$ & iNOS (A) & Belum diketahui \\
\hline Skin DC janin tikus & $\begin{array}{l}\text { LPS;TNF/ GM- } \\
\text { SCF }\end{array}$ & iNOS $(P, A)$ & $\begin{array}{l}\text { Apoptosis double positive } \\
\text { timosit? }\end{array}$ \\
\hline $\begin{array}{l}\text { DC timus } \\
\text { marmut/rat }\end{array}$ & $\begin{array}{l}\text { None; self } \\
\text { antigen; allo } \\
\text { antigen }\end{array}$ & $\begin{array}{l}\text { iNOS }(P, A) \\
\text { iNOS }(R, P, A)\end{array}$ & $\begin{array}{l}\text { Peningkatan : tyk2, } \\
\text { penglepasan } \\
\text { IFN } \gamma \text {, sitotoksisitas. }\end{array}$ \\
\hline $\begin{array}{l}\text { Sel NK empedu } \\
\text { tikus }\end{array}$ & $\begin{array}{l}\text { IL2 /+IL12; IFN } \\
\alpha / \beta\end{array}$ & iNOS $(R, P)$ & Ekspresi perforin \\
\hline NK cell line & Gestation & iNOS $(R, P, A)$ & $\begin{array}{l}\text { Peningkatan : sitotoksisitas, } \\
\text { penglepasan IFN } \gamma \text {. }\end{array}$ \\
\hline Sel NK uteri tikus & IL2 & iNOS $(R, P, A)$ & $\begin{array}{l}\text { Menekan : sitotoksisitas, } \\
\text { ekspresi granzym B }\end{array}$ \\
\hline $\begin{array}{l}\text { Sel NK (darah, } \\
\text { empedu) rat }\end{array}$ & IL12 +/TNF & $\begin{array}{l}\text { eNOS }(R, P, A) ; \text { no } \\
\text { iNOS }\end{array}$ & Anti apoptetik \\
\hline $\begin{array}{l}\text { Sel NK (darah } \\
\text { mnsia) }\end{array}$ & $\begin{array}{l}\text { IL2 +anti CD16 / } \\
\text { target sel kontak }\end{array}$ & nNOS $(P, A) \quad$ sel T & Pro-apoptetik \\
\hline $\begin{array}{l}\text { Sel/line NK (darah } \\
\text { mnsia) }\end{array}$ & Anti CD3 & iNOS (R) & Replikasi virus \\
\hline $\begin{array}{l}\text { Hibridoma sel T } \\
\text { Tikus }\end{array}$ & Infeksi HIV1 & $\begin{array}{l}\text { iNOS (P); no iNOS } \\
(\mathrm{R})\end{array}$ & Anti-apoptetik \\
\hline Sel T leukemik & & iNOS $(R, P, A)$ & \\
\hline
\end{tabular}


Disadur dari Bogdan, 2001

ATL; adult T cell Leukemia, BM: Bone Marrow, CLL: cronic lymphocytic leukemia, DC: Dendric cell, LC: Langerhans cell, PHA: phytohemaglutinin, SDF stroma cell derive factor,

R:mRNA, P: Protein, A: Enzym Activity

Walaupun iNOS tidak ada, jika IL18 ada maka produksi IFN- $\gamma$ oleh sel NK tidak terganggu 